\title{
Faktor Somatogenik, Psikogenik, Sosiogenik yang Merupakan Faktor Risiko Kejadian Skizofrenia Usia < 25 Tahun (Studi di Kecamatan Kepil Kabupaten Wonosobo)
}

\author{
Dhian Ika Prihananto", Suharyo Hadisaputro ${ }^{* *}$, Mateus Sakundarno Adi ${ }^{* * *}$ \\ "Universitas Nusantara PGRI Kediri, "** Politeknik Kesehatan Semarang, ${ }^{* * * *}$ Fakultas Kesehatan \\ Masyarakat Undip
}

\begin{abstract}
Background : Schizophrenia is a clinical syndrom of several disturbing psichological condition, involving process of thinking, emotion, perception, and attitude. Risks factors contributing to the appearance of schizophrenia $<25$ years old are factors of somatogenic, psychogenic, and sociogenic. The aim of the reaearch was to povide evidence that factors of somatogenic, psychogenic, and sociogenic are contributing factors to schizophrenia $<25$ years old.

Methods : This research is a research of mix method, design of case-control study reinforced by indepht interview. The population of study was people with schizophrenia $<25$ years old in Kepil Subdistrict, Wonosobo Regency. The sample consisted of 55 cases and 55 controls based on consecutive samplung. The research instrument was guided interview. Data were then analyzed using chi square (univariate, bivariate) and logistic regression (multivariate).

Result : Contributing factors to risk factors of schizophrenia observed on people $<25$ years old are family with schizophrenia $(\mathrm{OR}=8,01695 \% \mathrm{CI}=2,342-27,433 \mathrm{p}=0,001)$, bad temper $(\mathrm{OR}=3,22395 \% \mathrm{CI}=1,159-8,961 \mathrm{p}=0,025)$, early deprivation $(\mathrm{OR}=5,35695 \% \mathrm{CI}=1,180-24,309$ $\mathrm{p}=0,030)$, experiencing stress $(\mathrm{OR}=5,45195 \% \mathrm{CI}=1,739-17,083 \mathrm{p}=0,004)$, low social development $(\mathrm{OR}=3,36395 \% \mathrm{CI}=1,072-10,552 \mathrm{p}=0,038)$, low economic condition $(\mathrm{OR}=5,294$ $95 \% \mathrm{CI}=1,696-16,524 \mathrm{p}=0,004)$.

Conclusion : Somatogenic factor that proved to be a risk factor for schizophrenia $<25$ years old is having a family history of schizophrenia, has a bad temper. Psychogenic factors are experiencing early deprivation, experiencing stress. Sociogenic factor is bad social development, low economic level.
\end{abstract}

Keywords : Schizophrenia; risk factors; factors of somatogenic psychogenic sociogenic; age $<25$ years old

*Penulis korespondensi : dhianre2@yahoo.com 


\section{Pendahuluan}

Skizofrenia adalah suatu penyakit yang mempengaruhi otak dan menyebabkan timbulnya pikiran, presepsi, emosi, gerakan, dan perilaku yang aneh dan terganggu. ${ }^{\prime}$ Skizofrenia terkait dengan stres, gangguan neurobiologis yang ditandai dengan gangguan pikiran. ${ }^{2}$ Penyakit skizofrenia memang masih kurang populer di kalangan masyarakat awam. Namun gangguan jiwa ini sudah mulai mencemaskan karena sampai sekarang penanganannya masih belum memuaskan. Di masa lalu banyak orang menganggap skizofrenia merupakan penyakit yang tidak dapat diobati. Seiring dengan kemajuan dibidang ilmu kedokteran jiwa maka kini anggapan itu mulai hilang dan diakui skizofrenia sebenarnya termasuk gangguan kesehatan dan termasuk dalam ilmu kedokteran jiwa (psikiatri) yang penanganannya sesuai dengan terapi kedokteran sebagaimana halnya penyakit fisik lainnya. ${ }^{3}$

Seringkali pasien skizofrenia digambarkan sebagai individu yang bodoh, aneh, dan berbahaya. ${ }^{4}$ Sebagai konsekuensi kepercayaan tersebut, banyak pasien skizofrenia tidak dibawa berobat ke dokter (psikiater) melainkan disembunyikan, kalaupun akan dibawa berobat, mereka tidak dibawa ke dokter melainkan dibawa ke "orang pintar". 3

Kesehatan jiwa masih menjadi salah satu permasalahan kesehatan yang signifikan di dunia, termasuk indonesia. Menurut WHO pada tahun 2016 terdapat sekitar 35 juta orang menderita depresi,60 juta orang menderita bipolar, 21 juta menderita skizofrenia, serta 47,5 juta menderita dimensia. ${ }^{5}$ Menurut WHO bahwa 5-15\% dari anak-anak antara 3-15 tahun mengalami gangguan jiwa yang persistent dan mengganggu hubungan sosial. ${ }^{6}$ Berdasarkan data yang diperoleh di negara Amerika Serikat setiap tahun, terdapat 300.000 pasien skizofrenia mengalami episode akut, hampir 20\%-50\% pasien skizofrenia melakukan percobaan bunuh diri, dan $10 \%$ di antaranya berhasil (mati bunuh diri), dapat disimpulkan angka kematian pasien skizofrenia 8 kali lebih tinggi dari angka kematian penduduk pada umumnya. ${ }^{(7)}$

Berdasarkan data riskesdas tahun 2007 memperlihatkan bahwa prevalensi gangguan jiwa berat di Indonesia adalah sebesar 4,6 per mil. Prevalensi tertinggi terdapat di provinsi DKI Jakarta sebesar 20,3 per mil yang kemudian secara berturut-turut diikuti oleh provinsi Nanggroe Aceh Darusalam sebesar 18,5 per mil, Sumatera Barat sebesar 16,7 per mil, Nusa Tenggara Barat sebesar 9,9 per mil, Sumatera Selatan sebesar 9,2 per mil. ${ }^{8}$ Berdasarkan data riskesdas tahun 2013 memperlihatkan prevalensi gangguan jiwa berat nasional sebesar 1,7 per mil. Prevalensi tertinggi terdapat di provinsi Aceh dan DI Yogyakarta sebesar 2,7 per mil, kemudian secara berturut-turut diikuti oleh provinsi Sulawesi Selatan sebesar 2,6 per mil, provinsi Jawa Tengah dan Bali sebesar 2,3 Per mil. ${ }^{9}$

Berdasarkan data BPS pada tahun 2015 kabupaten Wonosobo merupakan kabupaten termiskin di provinsi Jawa Tengah dengan presentasi penduduk miskin sebesar $22.02 \% .^{10}$ Kabupaten Wonosobo memiliki berbagai masalah kesehatan dan masalah sosial, salah satu masalah kesehatan dan sosial yang dihadapi adalah masalah kesehatan jiwa. Berdasarkan data riskesdas provinsi Jawa Tengah tahun 2007 prevalensi skizofrenia di kabupaten Wonosobo sebesar 4,0 per mil. ${ }^{(11)}$ Berdasarkan data riskesdas provinsi Jawa Tengah tahun 2013 prevalensi skizofrenia di kabupaten Wonosobo sebesar 1,5 per mil. $^{12}$

Kecamatan Kepil merupakan salah satu kecamatan di kabupaten Wonosobo yang memiliki penderita skizofrenia yang cukup banyak yaitu pada tahun 2013 sampai 2016 sebesar 87 penderita skizofrenia. Kecamatan Kepil terdiri dari 2 Puskesmas yaitu Puskesmas Kepil 1 dan Puskesmas Kepil 2. Jumlah penderita skizofrenia di kecamatan Kepil yaitu data dari Puskesmas Kepil 1 jumlah penderita skizofrenia pada tahun 2013 sampai 2016 sebanyak 64 penderita, yang meninggal 2 orang, sembuh 1 orang, pergi lorang, dimana ada 39 penderita skizofrenia mulai mengidapnya pada usia $<$ 25 tahun. ${ }^{13}$ Data dari Puskesmas Kepil 2 jumlah penderita skizofrenia pada tahun 2016 sebanyak 23 penderita, dimana ada 16 
penderita skizofrenia mulai mengidapnya pada usia $<25$ tahun. ${ }^{14}$

Gangguan jiwa skizofrenia tidak terjadi dengan sendirinya begitu saja, tetapi banyak faktor yang menyebabkan terjadinya skizofrenia. Faktor-faktor yang menyebabkan terjadinya skizofrenia yaitu faktor somatogenik, psikogenik, sosiogenik. ${ }^{7}$ Faktor somatogenik yaitu keturunan, cacat kongenital, kelainan otak, temperamen, penyakit dan cedera tubuh. Faktor psikogenik yaitu perkembangan psikologi, deprivasi dini, pola keluarga, stress, penyalahgunaan obat-obatan. Sedangkan yang termasuk faktor sosiogenik yaitu perkembangan sosial, cita-cita, tingkat ekonomi, perpindahan kesatuan keluarga. ${ }^{7,15}$

Banyaknya penderita skizofrenia terutama usia $<25$ tahun dan belum adanya penelitian tentang faktor risiko skizofrenia dikabupaten Wonosobo terutama di kecamatan Kepil maka penulis tertarik melakukan penelitian dengan judul faktor somatogenik, psikogenik, sosiogenik yang merupakan faktor risiko kejadian skizofrenia usia $<25$ tahun di kecamatan Kepil kabupaten Wonosobo.

\section{Metode}

Penelitian ini merupakan penelitian mix method, desain studi case-control yang diperkuat dengan indepht interview. Populasi studi yaitu penderita skizofrenia usia $<25$ tahun di kecamatan Kepil kabupaten Wonosobo. Sampel terdiri dari 55 kasus dan 55 kontrol yang diambil secara consecutive sampling. Variabel terikat dalam penelitian ini adalah penderita skizofrenia usia $<25$ tahun sedangkan Variabel bebas dalam penelitian ini yaitu faktor somatogenik (keturunan, cacat kongenital, kelainan otak, temperamen, penyakit dan cedera tubuh), faktor psikogenik (perkembangan psikologik, deprivasi dini, pola keluarga, stress, penyalahgunaan obatfaktor sosiogenik (perkembangan sosial, cita-cita, tingkat ekonomi,obatan), perpindahan kesatuan keluarga). Instrument penelitian adalah kuesioner wawancara. Analisis data secara univariat, bivariat (chisquare), dan multivariat (regresi logistik).

\section{Hasil}

Berdasarkan hasil analisis bivariat dengan uji chi-square diketahui bahwa variabel yang terbukti sebagai faktor risiko skizofrenia usia $<25$ tahun yaitu keturunan, temperamen, deprivasi dini, pola keluarga, stress, perkembangan sosial, cita-cita, tingkat ekonomi, perpindahan kesatuan keluarga.

Tabel 1. Hasil analisis bivariat variabel bebas terhadap kejadian skizofrenia usia $<25$ tahun.

\begin{tabular}{|c|c|c|c|}
\hline Variabel & OR & $95 \% \mathrm{CI}$ & $\mathrm{P}$ \\
\hline $\begin{array}{l}\text { 1. Mempunyai riwayat keluarga } \\
\text { skizofrenia }\end{array}$ & 3,234 & $\begin{array}{r}1,355- \\
7,719\end{array}$ & 0,013 \\
\hline 2. Mengalami cacat kongenital & 1,000 & $0,061-$ & 1,000 \\
\hline 3. Ada kelainan otak & 2,038 & $\begin{array}{c}16,401 \\
0,179- \\
23,151\end{array}$ & 1,000 \\
\hline $\begin{array}{l}\text { 4. Mempunyai temperamen } \\
\text { buruk }\end{array}$ & 3,783 & $\begin{array}{r}1,687- \\
8,482\end{array}$ & 0,002 \\
\hline $\begin{array}{l}\text { 5. Menderita penyakit dan cedera } \\
\text { tubuh }\end{array}$ & 1,000 & $\begin{array}{l}0,061- \\
16,401\end{array}$ & 1,000 \\
\hline $\begin{array}{l}\text { 6. Perkembangan psikologi tidak } \\
\text { sesuai }\end{array}$ & 2,650 & $\begin{array}{l}0,492- \\
14,286\end{array}$ & 0,438 \\
\hline 7. Mengalami deprivasi dini & 5,365 & $\begin{array}{l}1,434- \\
20,076\end{array}$ & 0,015 \\
\hline 8. Pola keluarga tidak sesuai & 3,877 & $\begin{array}{r}1,711- \\
8,783\end{array}$ & 0,002 \\
\hline 9. Mengalami stress & 4,317 & $\begin{array}{r}1,930- \\
9,657\end{array}$ & 0,001 \\
\hline 10. Menyalahgunakan obat-obatan & 1,359 & $\begin{array}{r}0,290- \\
6,379\end{array}$ & 1,000 \\
\hline 11. Perkembangan sosial buruk & 3,586 & $\begin{array}{r}1,538- \\
8,362\end{array}$ & 0,005 \\
\hline 12. Cita-cita tidak tercapai & 3,656 & $\begin{array}{r}1,654- \\
8,084\end{array}$ & 0,002 \\
\hline 13. Tingkat ekonomi rendah & 3,857 & $\begin{array}{r}1,655- \\
8,990\end{array}$ & 0,003 \\
\hline $\begin{array}{l}\text { 14. Mengalami perpindahan } \\
\text { kesatuan keluarga }\end{array}$ & 3,415 & $\begin{array}{l}1,135- \\
10,273\end{array}$ & 0,044 \\
\hline 15. Tingkat pendidikan rendah & 2,636 & $\begin{array}{r}1,218- \\
5,705\end{array}$ & 0,022 \\
\hline
\end{tabular}

Berdasarkan hasil analisis multivariat logistik terdapat tujuh variabel bebas yang terbukti berpengaruh terhadap kejadian skizofrenia usia $<25$ tahun yaitu keturunan, temperamen, deprivasi dini, stress, perkembangan sosial, tingkat ekonomi rendah dan tingkat pendidikan rendah. Variabel yang bisa diperbaiki yaitu temperamen, deprivasi dini, stress, perkembangan sosial, tingkat ekonomi rendah dan tingkat pendidikan rendah. 
Berdasarkan analisis multivariat dengan variabel keturunan menunjukan bahwa kejadian skizofrenia usia $<25$ tahun 8 kali lebih sering terjadi pada orang yang berusia $<$ 25 tahun yang mempunyai riwayat keluarga skizofrenia dibandingkan dengan yang tidak mempunyai riwayat keluarga skizofrenia $(\mathrm{OR}=8,016 \quad 95 \% \mathrm{CI}=2,342-27,433)$. Berdasarkan analisis multivariat dengan variabel temperamen menunjukkan bahwa kejadian skizofrenia usia $<25$ tahun 3 kali lebih sering terjadi pada orang yang berusia $<$ 25 tahun yang mempunyai temperamen buruk dibandingkan dengan yang mempunyai temperamen baik $(\mathrm{OR}=3,223$ $95 \% \mathrm{CI}=1,159-8,961)$. Berdasarkan analisis multivariat dengan variabel deprivasi dini menunjukan bahwa kejadian skizofrenia usia $<25$ tahun 5,4 kali lebih sering terjadi pada orang yang berusia $<25$ tahun yang mengalami deprivasi dini dibandingkan dengan yang tidak mengalami deprivasi dini $(\mathrm{OR}=5,35695 \% \mathrm{C} \mathrm{I}=1,180$ 24,309).Berdasarkan analisis multivariat dengan variabel stress menunjukan bahwa kejadian skizofrenia usia $<25$ tahun $5,5 \mathrm{kali}$ lebih sering terjadi pada orang yang berusia $<$ 25 tahun yang mengalami stress dibandingkan dengan yang tidak mengalami stress $(\mathrm{OR}=5,45195 \% \mathrm{CI}=1,739-17,083)$. Berdasarkan analisis multivariat dengan variabel perkembangan sosial menunjukan bahwa kejadian skizofrenia usia $<25$ tahun 3,4 kali lebih sering terjadi pada orang yang berusia $<25$ tahun yang perkembangan sosial buruk dibandingkan dengan yang perkembangan sosial baik $(\mathrm{OR}=3,363$ $95 \% \mathrm{CI}=1,072-10,552)$. Berdasarkan analisis multivariat dengan variabel tingkat ekonomi menunjukan bahwa kejadian skizofrenia usia $<25$ tahun 5,3 kali lebih sering terjadi pada orang yang tingkat ekonomi rendah dibandingkan dengan tingkat ekonomi tinggi $(\mathrm{OR}=5,294$ 95\% CI $=1,696-16,524)$. Berdasarkan analisis multivariat dengan variabel tingkat pendidikan menunjukan bahwa kejadian skizofrenia usia $<25$ tahun 2,4 kali lebih sering terjadi pada orang yang berusia $<25$ tahun yang tingkat pendidikan rendah dibandingkan dengan yang tingkat pendidikan tinggi $(\mathrm{OR}=2,39695 \% \mathrm{CI}$
$=0,842-6,822)$.

Tabel 2. Hasil analisis multivariat yang bermakna secara statistik

\begin{tabular}{|c|c|c|c|c|c|}
\hline Variabel & $\mathrm{B}$ & Wald & $\operatorname{Exp}(\mathrm{B})$ & $95 \% \mathrm{CI}$ & $\mathrm{P}$ \\
\hline Mempunyai riwayat & 2,081 & 10,996 & 8,016 & $2,342-$ & 0,001 \\
\hline keluarga skizofrenia & & & & 27,433 & \\
\hline Mempunyai & 1,170 & 5,032 & 3,223 & 1,159 & 0,025 \\
\hline ramen bur & & & & 8,961 & \\
\hline Mengalami & 1,678 & 4,730 & 5,356 & $1,180-$ & 0,030 \\
\hline depri & & & & 24,309 & \\
\hline Mengalami & 1,696 & 8,466 & 5,451 & $1,739-$ & 0,004 \\
\hline stress & & & & 17,083 & \\
\hline Perkembangan & 1,213 & 4,321 & 3,363 & $1,072-$ & 0,038 \\
\hline sosial buruk & & & & 10,552 & \\
\hline Tingkat ekonomi & 1,667 & 8,236 & 5,294 & $1,696-$ & 0,004 \\
\hline rendah & & & & 16,524 & \\
\hline Tingkat pendidikan & 0,874 & 2,680 & 2,396 & $0,842-$ & 0,102 \\
\hline rendah & & & & 6,822 & \\
\hline Constant & $-3,765$ & 22,118 & 0,023 & & 0,000 \\
\hline
\end{tabular}

Model persamaan regresi logistik untuk memprediksi atau memperkirakan peluang untuk terjadinya skizofrenia usia < 25 tahun dari ke tuju variabel (keturunan, temperamen, deprivasi dini, stress, perkembangan sosial, tingkat ekonomi, tingkat pendidikan) tersebut bila dihitung berdasarkan rumus probability event adalah sebagai berikut:

$$
\begin{aligned}
& \mathrm{p}=\frac{1}{1+\mathrm{e}^{-(\mathrm{y}+\mathrm{b} 1 \times 1+\mathrm{b} 2 \times 2 \times+\mathrm{b} 3 \times 3+\mathrm{b} 4 \times 4)} \times 100 \%} \\
& \mathrm{p}=\frac{1}{1+2,718^{-(-3,7,755+(2,081) 1+(1,170) 1+(1,678) 1+(1,696) 1+(1,213) 1+(1,667)}} \\
& \mathrm{p}=99.87 \%
\end{aligned}
$$

Persamaan regresi logistik menunjukkan bahwa mempunyai riwayat keluarga skizofrenia, mempunyai temperamen buruk, mengalami deprivasi dini, mengalami stress, perkembangan sosial buruk, tingkat ekonomi rendah, dan tingkat pendidikan rendah memiliki probabilitas untuk menderita skizofrenia usia $<25$ tahun sebesar 99,87\%.

\section{Pembahasan}

\section{Faktor yang terbukti sebagai faktor risiko kejadian skizofrenia usia $<25$ tahun}

1. Keturunan

Hasil penelitian ini menunjukan bahwa mempunyai riwayat keluarga skizofrenia sebagai faktor risiko kejadian skizofrenia 
usia $<25$ tahun di kecamatan Kepil kabupaten Wonosobo. Presentase responden pada kelompok kasus yang mepunyai riwayat keluarga skizofrenia yaitu sebesar $41,8 \%$, lebih banyak dibandingkan pada kelompok kontrol sebesar $18,2 \%$. Mempunyai riwayat keluarga skizofrenia mempunyai faktor risiko sebesar 8 kali (nilai $\mathrm{p}=0,001$ OR $=8,016 \quad 95 \% \mathrm{CI}=2,342-$ 27,433 ) lebih besar terkena skizofrenia usia < 25 tahun dibandingkan dengan yang tidak mempunyai riwayat keluarga skizofrenia.

Hasil penelitian ini sejalan dengan penelitian Handayani yang menyebutkan bahwa ada hubungan antara faktor keturunan dengan kejadian skizofrenia. Nilai $p=0,048$, nilai RP 1,195 dengan CI 95\% 1,004-1,423, artinya orang yang memiliki faktor ketrunan berisiko 1,195 kali lebih besar terkena skizofrenia dibandingkan dengan orang yang tidak memiliki faktor keturunan. ${ }^{16}$ Penelitian Amirudin, yang menyatakan bahwa riwayat keturunan (faktor keturunan) memiliki hubungan dengan kejadian skizofrenia dengan nilai $p$ value $0,00(p<0,05) .{ }^{17}$ Penelitian Setiyowati menyatakan bahwa ada hubungan antara riwayat keluarga dengan kejadian skizofrenia $(\mathrm{p}=0,000) .{ }^{18}$

Menurut Arif, berbagai penelitian menunjukan bahwa gen yang diwariskan seseorang sangat kuat mempengaruhi resiko seseorang mengalami skizofrenia. Studi pada keluarga telah menunjukkan bahwa semakin dekat relasi seseorang dengan pasien skizofrenia, semakin besar risikonya untuk menderita penyakit skizofrenia. ${ }^{19}$ Berdasarkan teori Blum (1974) dalam Notoatmojo bahwa derajat kesehatan masyarakat dipengaruhi oleh empat faktor yaitu genetik, pelayanan kesehatan, perilaku, dan lingkungan yang saling mempengaruhi satu sama lain. Faktor keturunan memiliki resiko lebih besar terkena skizofrenia apabila dipengaruhi oleh stresor psikososial baik berasal dari diri sendiri maupun lingkungan. ${ }^{20}$

Data dilapangan menunjukan perbandingan penderita skizofrenia usia $<25$ tahun dengan keturunan lebih banyak terjadi pada kelompok kasus daripada kelompok kontrol. Dengan melakukan konsultasi ke pelayanan kesehatan jiwa apabila salah satu keluarga memilki riwayat skizofrenia, sehingga stresor psikososial yang mempengaruhi terjadinya skizofrenia akibat faktor keturunan dapat diminimalisir. Dengan menghindari perkawinan sesama penderita skizofrenia atau keluarga yang mempunyai riwayat skizofrenia akan meminimalisir faktor keturunan.

\section{Temperamen}

Hasil penelitian ini menunjukan bahwa mempunyai temperamen buruk sebagai faktor risiko kejadian skizofrenia usia $<25$ tahun di kecamatan Kepil kabupaten Wonosobo. Presentase responden pada kelompok kasus yang mempunyai temperamen buruk yaitu sebesar $56,4 \%$, lebih banyak dibandingkan pada kelompok kontrol sebesar 25,5\%. Mempunyai temperamen buruk mempunyai faktor risiko sebesar 3,2 kali (nilai $\mathrm{p}=0,025 \mathrm{OR}=3,223$ $95 \% \mathrm{CI}=1,159-8,961)$ lebih besar terkena skizofrenia usia $<25$ tahun dibandingkan dengan yang mempunyai temperamen baik.

Hasil penelitian ini sejalan dengan penelitian Fadli yang menyebutkan bahwa ada hubungan signifikan antara faktor tipe kepribadian dengan kejadian gangguan jiwa dengan nilai $\mathrm{p}=0,000(\mathrm{p}<0,05)$. Tipe kepribadian introvert memiliki 6,7 kali lebih besar untuk mengalami gangguan jiwa $(\mathrm{OR}=$ $6,667) .{ }^{21}$ Individu yang memiliki kepribadian skizoid dengan ciri-ciri pemalu, pendiam, suka menyendiri, perasa, emosi dan temperamen dingin, menghindar dari hubungan hubungan jangka panjang dengan orang lain. Individu ini menunjukan respon yang terbatas terhadap isyarat atau rangsangan sosial, jadi individu ini cenderung lebih mudah mengalami gangguan jiwa. ${ }^{6}$ Sesorang yang memilki tipe kepribadian pendiam atau introvert lebih rentan terjadinya gangguan jiwa. ${ }^{22}$ Orang yang terlalu peka atau sensitif biasanya mempunyai masalah kejiwaan dan ketegangan yang memilki kecenderungan mengalami gangguan jiwa.

\section{Deprivasi dini}

Hasil penelitian ini menunjukan bahwa mengalami deprivasi dini sebagai faktor risiko kejadian skizofrenia usia $<25$ 
tahun di kecamatan Kepil kabupaten Wonosobo. Presentase responden pada kelompok kasus yang mengalami deprivasi dini yaitu sebesar 23,6\%, lebih banyak dibandingkan pada kelompok kontrol sebesar 5,5\%. Mengalami deprivasi dini mempunyai faktor risiko sebesar 5,4 kali (nilai $\mathrm{p}=0,030 \mathrm{OR}=5,35695 \% \mathrm{CI}=1,180$ 24,309) lebih besar terkena skizofrenia usia < 25 tahun dibandingkan dengan yang tidak mengalami deprivasi dini.

Hasil penelitian ini tidak sejalan dengan penelitian Erlina yang menunjukan tidak terdapat perbedaan yang bermakna antara timbulnnya skizofrenia dan non skizofrenia berdasar perpisahan orang tua. ${ }^{23}$

Hasil penelitian ini tidak sesuai dengan penelitian Mallet et al. yang melakukan penelitian pada etnik asia yang menyatakan tidak terdapat hubungan yang antara terpisah dengan orang tua terhadap timbulnya skizofrenia $(\mathrm{p}=0,34)$. Hasil penelitian ini sesuai dengan penelitian Mallet et al yang melakukan penelitian pada etnik Afrikakaribbia yang menyatakan bahwa ada hubungan yang bermakna antara terpisah dengan orang tua terhadap timbulnya skizofrenia $(\mathrm{OR}=5,00 \quad 95 \% \mathrm{CI}: 1,09-22,82$ $\mathrm{p}=0,038){ }^{(24)}$

Makin lama makin nyata bahwa deprivasi (ketidakperolehan) biologis atau psikologis pada waktu bayi dapat mengakibatkan kerusakan yang tidak dapat diperbaiki lagi. Deprivasi maternal atau kehilangan asuhan ibu dirumah sendiri, terpisah dengan ibu atau tinggal diasrama, dapat menimbulkan perkembangan yang abnormal. Deprivasi rangsangan umum dari lingkungan, bila sangat berat ternyata berhubungan dengan retardasi mental. Deprivasi atau frustrasi dini dapat menimbulkan titik-titik-titik lemah pada jiwa, juga dapat mengakibatkan perkembangan yang salah atau pun perkembangan yang berhenti. Untuk perkembangan psikologis rupanya ada masa-masa gawat. Dalam masa ini rangsangan dan pengalaman belajar yang berhubungan dengan perkembangan psikologis serta pemuasan berbagai kebutuhan sangat perlu bagi urutan-urutan perkembangan intelektual, emosional dan sosial yang norma.

Perpecahan dalam keluarga, perceraian orang tua, adopsi, kematian orang tua merupakan satu dari faktor risiko untuk perkembangan anak, jelasnya tidak hanya perpisahan itu sendiri tetapi periode yang panjang dari perselisihan dan banyaknya ketidakharmonisan yang akhirnya menimbulkan gangguan pada anak. Perlunya hubungan kekerabatan pada masyarakat sehingga seorang anak masih mendapatkan kasih sayang dari keluarga lain.

\section{4. $\quad$ Stress}

Hasil penelitian ini menunjukan bahwa mengalami stress sebagai faktor risiko kejadian skizofrenia usia $<25$ tahun di kecamatan Kepil kabupaten Wonosobo. Presentase responden pada kelompok kasus yang mengalami stress yaitu sebesar $72,7 \%$, lebih banyak dibandingkan pada kelompok kontrol sebesar 38,2\%. Mengalami stress mempunyai faktor risiko sebesar 5,5 kali (nilai $\mathrm{p}=0,004 \mathrm{OR}=5,45195 \% \mathrm{CI}=1,739$ 17,083) lebih besar terkena skizofrenia usia < 25 tahun dibandingkan dengan yang tidak mengalami stress.

Hasil penelitian ini sejalan dengan penelitian Hidayat (2013) yang menyatakan bahwa ada hubungan yang signifikan antara masalah psikosoial dengan kejadian skizofrenia dengan nilai $\mathrm{p}=0,005 \quad(\mathrm{p}<0,05)$ dan $\mathrm{OR}=13,750$ artinya responden yang memiliki masalah psikososial berpeluang 13,7 kali beresiko mengalami gangguan skizofrenia dibandingkan dengan responden yang tidak memiliki masalah psikososial. ${ }^{25}$

Hasil penelitian ini sejalan dengan penelitian Setiyowati tahun 2012 yang menunjukan bahwa ada hubungan antara stressor psikososial dengan kejadian skizofrenia faktor dominan yang berperan terhadap kejadian skizofrenia yaitu masalah hubungan interpersonall. Purnama tahun 2016 yang menunjukan bahwa sebagian besar jumlah penderita gangguan jiwa disebabkan karena stress sebanyak 140 responden (90,3\%), sedangkan yang disebabka bukan karena stress sebanyak $(3,9 \%){ }^{26}$

Keadaan tegang ini secara biopsikososial yang dialami biasanya 
bersumber dari setiap keadaan atau peristiwa yang menyebabkan perubahan dalam hidupnya sehingga ia terpaksa mengadakan adaptasi untuk penanggulangan stressor kejadian pada kehidupan penderita seperti masalah perkawinan, problem orang tua, hubungan interpersonal, masalah pekerjaan, lingkungan hidup, masalah keuangan, keterlibatan hukum, perkembangan fisik, penyakit fisik, faktor keluarga, dan lain-lain. Semuanya merupakan faktor psikososial yang dilaporkan berperan pada gangguan skizofrenia. ${ }^{7}$

Peristiwa individu yang dialami oleh pasien baik dilingkungan keluarga, masyarakat dan tempat kerja terkadang menimbulkan tekanan yang pada tingkat tertentu akan mempengaruhi kesehatan mentalnya. Jika stresor tersebut berlangsung terus menerus dalam jangka waktu panjang, individu tersebut dapat kehabisan daya tahan dalam menerima stresor, mengalami kelelahan mental dan pada akhirnya akan memasuki kondisi depresi dan jika berlarutlarut dapat menimbulkan skizofrenia. ${ }^{(27)}$

\section{Perkembangan sosial}

Hasil penelitian ini menunjukan bahwa perkembangan sosial buruk sebagai faktor risiko kejadian skizofrenia usia $<25$ tahun di kecamatan Kepil kabupaten Wonosobo. Presentase responden pada kelompok kasus yang perkembangan sosial buruk yaitu sebesar 47,3\%, lebih banyak dibandingkan pada kelompok kontrol sebesar $20 \%$. perkembangan sosial buruk mempunyai faktor risiko sebesar 3,4 kali (nilai $\mathrm{p}=0,038$ $\mathrm{OR}=3,36395 \% \mathrm{CI}=1,072-10,552)$ lebih besar terkena skizofrenia usia $<25$ tahun dibandingkan dengan yang perkembangan sosialnya baik.

Hasil penelitian ini sejalan dengan penelitian yang dilakukan Tanjung Laksono Utomo yang menyebutkan bahwa ada hubungan antara faktor sosiokultural dengan kejadian skizofrenia dengan nilai $\mathrm{p}=0,040$ $(\mathrm{p}=<0,05)$ OR $=3,454$ artinya bahwa responden yang mempunyai masalah sosiokultural berisiko 3 kali lebih besar dibandingkan yang tidak mempunyai masalah sosiokultural. ${ }^{28}$ Penelitian ini sejalan dengan penelitan yang dilakukan oleh Sari yang menyatakan bahwa faktor sosiokultural dan lingkungan yang memicu terjadinya skizofrenia adalah diintimidasi di lingkungan sosial. ${ }^{29}$ Rinawati (2016) yang menyatakan bahwa penyebab gangguan jiwa pada aspek sosial terbanyak adalah konflik dengan keluarga atau teman. ${ }^{30}$

Perbedaan sistem nilai moral dan etika antara kebudayaan yang satu dengan yang lain, antara masa lalu dengan sekarang sering menimbulkan masalah-masalah kejiwaan. Begitu pula perbedaan moral yang diajarkan dirumah/sekolah dengan yang dipraktikan dimasyarakat sehar-hari. Faktor budaya bukan merupakan penyebab langsung timbulnya gangguan jiwa, biasanya terbatas menentukan warna gejala-gejala. Disamping mempengaruhi pertumbuhan dan perkembangan kepribadian seseorang misalnya melalui aturan-aturan kebiasaan yang berlaku dalam kebudayaan tersebut.

Berdasarkan data dilapangan bahwa masih ada kebudayaan masyarakat di kecamatan kepil yang melakukan pernikahan dini dan perjodohan sebesar 37 responden atau $33,6 \%$. Pernikahan dini dan perjodohan akan berdampak negatif terhadap mental dan psikologi anak. Anak akan menjadi pendiam, trauma, tersisih dan takut yang pada akhirnya akan menyebabkan gangguan jiwa.

\section{Tingkat Ekonomi}

Hasil penelitian ini menunjukan bahwa tingkat ekonomi rendah sebagai faktor risiko kejadian skizofrenia usia $<25$ tahun di kecamatan Kepil kabupaten Wonosobo. Presentase responden pada kelompok kasus yang tingkat ekonomi rendah yaitu sebesar $49,1 \%$, lebih banyak dibandingkan pada kelompok kontrol sebesar $20 \%$. Tingkat ekonomi rendah mempunyai faktor risiko sebesar 5,3 kali (nilai $\mathrm{p}=0,004 \mathrm{OR}=5,294$ $95 \% \mathrm{CI}=1,696-16,524)$ lebih besar terkena skizofrenia usia $<25$ tahun dibandingkan dengan yang tingkat ekonomi tinggi.

Hasil penelitian ini sejalan dengan penelitian yang dilakukan Erlina et al. (2010) yang menunjukan ada perbedaan yang bermakna antara skizofrenia dan non skizofrenia berdasar adanya status ekonomi $(\mathrm{OR}=6,00: 95 \% \mathrm{CI}: 2,52-14,60, \mathrm{p}=0,000)$. Status ekonomi rendah mempunyai risiko 
6,00 kali untuk mengalami gangguan jiwa skizofrenia dibandingkan status ekonomi tinggi. ${ }^{23} \mathrm{Hal}$ ini didukung pendapat Jean dan Caton (2005) yaitu ada beberapa faktor psikososial yang mempengaruhi gangguan jiwa skizofrenia, yaitu sosial ekonomi rendah dan stres lingkungan. ${ }^{31}$ Mallet et al (2002) menyatakan bahwa ada hubungan yang bermakna antara status pekerjaan dengan timbulnya skizofrenia $(\mathrm{OR}=5,5$ $95 \% \mathrm{CI}: 2,59-11,68 \mathrm{p}=0,000){ }^{24}$

Kemiskinan ditandai dengan sedikitnya dukungan, keselamatan, tidak adanya ruang sehingga terlalu sesak, tidak adanya kebebasan pribadi, ketidakpastian dalam masalah ekonomi yang akhirnya mungkin menimbulkan risiko kesehatan bagi keluarga. ${ }^{23}$

Dalam masyarakat modern kebutuhan makin meningkat dan persaingan makin meningkat dan makin ketat untuk meningkatkan ekonomi hasil-hasil teknologi modern. Memacu orang untuk bekerja lebih keras agar dapat memilikinya. Jumlah orang yang ingin bekerja lebih besar dari kebutuhan sehingga pengangguran meningkat, demikian pula urbanisasi meningkat, mengakibatkan upah menjadi rendah. Faktor-faktor gaji yang rendah, perumahan yang buruk, waktu istirahat dan berkumpul dengan keluarga sangat terbatas dan sebagainya merupakan sebagian hal yang mengakibatkan perkembangan kepribadian yang abnormal.

Data dilapangan menunjukan perbandingan penderita skizofrenia usia $<25$ tahun dengan ekonomi rendah lebih banyak terjadi pada kelompok kasus daripada kelompok kontrol. Untuk meningkatkan ekonomi masyarakat perlu diciptakan lapangan kerja yang mampu menyerap tenaga kerja sehingga pengangguran penyebab kemiskinan bisa berkurang, melakukan pelatihan kerja bagi orang yang kurang mampu sehingga memiliki bekal yang cukup untuk maju didunia usaha, memberikan subsidi bagi orang yang kurang mampu seperti pengobatan gratis, bantuan langsung tunai, menarik minat pengangguran dengan menaikkan upah minimum sehingga mereka berhasrat untuk bekerja.
Faktor yang tidak terbukti sebagai faktor risiko kejadian skizofrenia usia $<25$ tahun 1. Cacat Kongenital

Hasil analisis multivariat menunjukan bahwa variabel cacat kongenital tidak terbukti sebagai faktor risiko kejadian skizofrenia usia $<25$ tahun di kecamatan Kepil kabupaten Wonosobo. Presentase responden pada kelompok kasus yang mengalami cacat kongenital yaitu sebesar $1,8 \%$ sama dengan pada kelompok kontrol sebesar $1,8 \%$. Hasil penelitian ini sejalan dengan penelitian yang dilakukan oleh Utomo (2013) yang menyatakan bahwa cacat tubuh sejak lahir tidak banyak berperan terhadap kejadian skizofrenia. ${ }^{28}$

\section{Kelainan otak}

Hasil analisis multivariat menunjukan bahwa variabel kelainan otak tidak terbukti sebagai faktor risiko kejadian skizofrenia usia $<25$ tahun di kecamatan Kepil kabupaten Wonosobo. Presentase responden pada kelompok kasus yang ada kelainan otak yaitu sebesar 3,6\% lebih banyak dibandingkan pada kelompok kontrol sebesar $1,8 \%$. Hasil penelitian ini sejalan dengan penelitian yang dilakukan oleh Utomo (2013) yang menyatakan bahwa kerusakan neurotransmitter atau kerusakan otak tidak banyak berperan terhadap kejadian skizofrenia. ${ }^{28}$

\section{Penyakit dan cedera tubuh}

Hasil analisis multivariat menunjukan bahwa variabel penyakit dan cedera tubuh tidak terbukti sebagai faktor risiko kejadian skizofrenia usia $<25$ tahun di kecamatan Kepil kabupaten Wonosobo. Presentase responden pada kelompok kasus yang menderita penyakit dan cedera tubuh yaitu sebesar 1,8\% sama dengan pada kelompok kontrol sebesar $1,8 \%$.

Hasil penelitian ini tidak sesuai dengan penelitian yang dilakukan oleh Besral (2013) yang menyatakan bahwa ada hubungan penyakit kronis dengan kejadian gangguan metal emosional, semakin banyak jumlah penyakit kronis yang diderita oleh responden akan semakin besar risikonya untuk menderita gangguan mental emosional. Responden yang menderita 1 penyakit kronis 
mempunyai risiko 11 kali lebih besar. ${ }^{32}$

Variabel penyakit dan cedera tubuh tidak terbukti sebagai faktor risiko kejadian skizofrenia dibawah usia 25 tahun di kecamatan Kepil kabupaten Wonosobo. Hal ini karena hanya sebagian kecil penderita skizofrenia yang mengalami penyakit kronis dan koping individunya baik dan sudah mendapatkan pengobatan dari dokter.

\section{Perkembangan psikologi}

Hasil analisis multivariat menunjukan bahwa variabel perkembangan psikologi tidak terbukti sebagai faktor risiko kejadian skizofrenia usia $<25$ tahun di kecamatan Kepil kabupaten Wonosobo. Presentase responden pada kelompok kasus yang mengalami perkembangan psikologi tidak sesuai yaitu sebesar 9,1\% lebih banyak dibandingkan pada kelompok kontrol sebesar 3,6\%.

Hasil penelitian ini tidak sesuai dengan penelitian yang dilakukan oleh Hasmila Sari yang menyatakan bahwa gangguan jiwa yang disebabkan oleh trauma sebesar $71,6 \%$, dimana berada pada presentase tinggi. ${ }^{29}$

Variabel gangguan perkembangan yang salah tidak terbukti sebagai faktor risiko kejadian skizofrenia dibawah usia 25 tahun di kecamatan Kepil kabupaten Wonosobo. Hal ini karena hanya sebagian kecil kelompok kasus dan kelompok kontrol yang mengalami gangguan perkembangan atau traumatik pada masa anak-anak. Gangguan perkembangan hanya terjadi pada masa balita saja dan mereka yang mengalami trauma masa anak-anak memiliki koping individu yang baik. Perkembangan psikologi yang salah dalam penelitian ini yaitu gangguan perkembangan yang tidaksesuai dengan usia dan adanya traumatik pada masa anak-anak.

\section{Pola keluarga}

Hasil analisis multivariat menunjukan bahwa variabel pola keluarga tidak terbukti sebagai faktor risiko kejadian skizofrenia usia $<25$ tahun di kecamatan Kepil kabupaten Wonosobo. Presentase responden pada kelompok kasus yang mengalami pola keluarga tidak sesuai yaitu sebesar 54,5\% lebih banyak dibandingkan pada kelompok kontrol sebesar $23,6 \%$.

Hasil penelitian ini sejalan dengan penelitian yang dilakukan Erlina et al. (2010) yang menunjukan tidak ada perbedaan yang bermakna antara skizofrenia dan non skizofrenia berdasar adanya pola asuh keluarga $(\mathrm{OR}=0,605$ 95\% CI : 0,249$1,467 \mathrm{P}=0,266)^{.23}$

Dalam keadaan krisis timbul bermacam-macam perasaan yang tidak enak, seperti cemas, takut, rasa salah atau malu, tergantung pada keadaan. Pengaruh keluarga sangat menolong individu dalam mengatasi krisis sesuai dengan adat istiadat, kebudayaan atau pengalaman keluarga itu. Keluarga harus menolong individu agar ia secara aktif menemukan cara penyelesaian masalahnya dan bukan agar ia menghindar tantangan atau memakai mekanisme pembelaan yang sekedar untuk menghilangkan ketegangan. ${ }^{33}$

\section{Penyalahgunaan obat-obatan}

Hasil analisis multivariat menunjukan bahwa variabel penyalahgunaan obat-obatan tidak terbukti sebagai faktor risiko kejadian skizofrenia usia $<25$ tahun di kecamatan Kepil kabupaten Wonosobo. Presentase responden pada kelompok kasus yang menyalahgunakan obat-obatan terlarang yaitu sebesar 7,3\% lebih banyak dibandingkan pada kelompok kontrol sebesar $5,5 \%$.

Hasil ini tidak sesuai dengan penelitian Besral (2013), bahwa ada hubungan antara mengkonsumsi alkohol dengan kejadian gangguan mental emosional. Responden yang mengkonsumsi alkohol mempunyai risiko 1,7 kali lebih besar untuk menderita gangguan mental emosional (OR : 1,66 $95 \% \mathrm{CI}: 1,60-1,71 \mathrm{p}=<0,001){ }^{32}$

Variabel penyalahgunaan obat-obatan tidak terbukti sebagai faktor risiko kejadian skizofrenia usia $<25$ tahun di kecamatan Kepil kabupaten Wonosobo. Hal ini karena hanya sebagian kecil responden yang mempunyai riwayat mengkonsumsi obatobatan terlarang atau alkohol. Responden yang mengkonsumsi obat-obatan terlarang atau alkohol kemungkinan hanya mengkonsumsi dalam dosis kecil dan dalam jangka waktu yang tidak lama. 


\section{Cita-cita}

Hasil analisis multivariat menunjukan bahwa variabel cita-cita tidak terbukti sebagai faktor risiko kejadian skizofrenia usia $<25$ tahun di kecamatan Kepil kabupaten Wonosobo. Presentase responden pada kelompok kasus yang cita-cita tidak tercapai yaitu sebesar 60\% lebih banyak dibandingkan pada kelompok kontrol sebesar 29,1\%. Hasil penelitian ini sejalan dengan penelitian Erlina (2010) yang menunjukan tidak terdapat perbedaan yang bermakna antara timbulnya skizofrenia dan non skizofrenia berdasar gagal mencapai cita-cita. $^{23}$

\section{Perpindahan kesatuan keluarga}

Hasil analisis multivariat menunjukan bahwa variabel perpindahan kesatuan keluaraga tidak terbukti sebagai faktor risiko kejadian skizofrenia usia $<25$ tahun di kecamatan Kepil kabupaten Wonosobo. Presentase responden pada kelompok kasus yang mengalami perpindahan kesatuan keluarga yaitu sebesar 25,5\% lebih banyak dibandingkan pada kelompok kontrol sebesar 9,1\%.

Hasil penelitian ini tidak sesuai dengan penelitian Sundquist (2004), bahwa ada hubungan antara tingkat urbanisasi dan timbulnya pertama kali psikosis ${ }^{34}$ Khusus untuk anak yang sedang berkembang keprbadiannya, perubahan-perubahan lingkungan (kebudayaan dan pergaulan), cukup mengganggu. ' Meskipun demikian walaupun mereka mengalami perpindahan kesatuan keluarga tetapi mereka mampu menyesuaikan diri dengan lingkungan disekitarnya (kebudayaan dan pergaulan) sehingga tidak mengganggu kejiwaannya.

\section{Kesimpulan}

Faktor somatogenik yang terbukti sebagai faktor risiko kejadian skizofrenia usia $<25$ tahun yaitu ada riwayat keluarga skizofrenia dan temperamen buruk. Faktor psikogenik yang terbukti sebagai faktor risiko kejadian skizofrenia usia $<25$ tahun yaitu mengalami deprivasi dini, mengalami stress. Faktor sosiogenik yang terbukti sebagai faktor risiko kejadian skizofrenia usia $<25$ tahun yaitu perkembangan sosial buruk, tingkat ekonomi rendah. Probabilitas kejadian skizofrenia usia $<25$ tahun adalah sebesar $99,87 \%$ apabila orang yang berusia $<$ 25 tahun tersebut mempunyai riwayat keluarga skizofrenia, temperamen buruk, deprivasi dini, stress, perkembangan sosial buruk, tingkat ekonomi rendah dan tingkat pendidikan rendah.

\section{Ucapan Terimakasih}

Terimakasih kepada Puskesmas Kepil I dan Puskesmas Kepil II yang telah memberi izin dan arahan selama proses penelitian berlangsung.

\section{Daftar Pustaka}

1. Sheila L. Videbeck. 2008. Psychiatric Mental Health Nursing. Des Moines Area Community College Ankeny, Lowa.pp.347-377.

2. Fadli. 2010. Pengetahuan dan Ekspresi Emosi Keluarga serta Frekuensi Kekambuhan Penderita Skizofrenia. Jurnal Kesehatan Nasional;7.pp.10.

3. Hawari. 2010. Pendekatan Holistik Pada Gangguan Jiwa Skizofrenia . Jakarta:FKUI.

4. Irmansyah. 2006. Pencegahan dan Intervensi Dini Skizofrenia. Diunduh dari http//scizofrenia.web.id.

5. Kementerian Kesehatan Republik Indonesia. 2016. Peran Keluarga Dukung Kesehatan Jiwa Masyarakat.

6. Marasmis, W. F. 2009. Catatan Ilmu Kedokteran Jiwa. Surabaya: Airlangga University Press.pp.157-282.

7. Yosep, I. Keperawatan Jiwa. Bandung: Refika Aditama.pp.63-80.

8. Badan Penelitian dan Pengembangan Kesehatan. 2007. Riset Kesehatan Dasar (RISKESDAS) Jakarta:Kementerian Kesehatan.

9. Badan Penelitian dan Pengembangan Kesehatan. 2013. Riset Kesehatan Dasar (RISKESDAS ). Jakarta: Kementerian Kesehatan Republik Indonesia;

.10. BPS Propinsi Jawa Tengah. 2015. Daftar Kabupaten/Kota Miskin di Jawa Tengah 
11. Badan Penelitian dan Pengembangan Kesehatan. 2007. Riset Kesehatan Dasar(RISKESDAS) Propinsi Jawa Tengah. Dinas Kesehatan Propinsi Jawa Tengah. Semarang

12. Badan Penelitian dan Pengembangan kesehatan. Riset Kesehatan Dasar (RISKESDAS)Propinsi Jawa Tengah. Dinas Kesehatan Propinsi Jawa Tengah. Semarang.

13. Sumber Data Puskesmas Kepil 1.2016. Jumlah Penderita Skizof rena di Puskesmas Kepil 1.

14. Sumber Data Puskesmas Kepil 2. 2016. Jumlah Penderita Skizofren ia di Puskesmas Kepil 2.

15. Jeste, D.V. \& Mueser, K.T. 2008. Clinical Handbook of Schizophrenia. New York: Guilford Press.

16. Handayani, L, Febriani Rahmadani.A., Saufi.A. 2015. Faktor Risiko Kejadian Skizofrenia di Rumah Sakit Jiwa Grhasia Daerah Istimewa Yogyakarta. Jurnal Humanitas;3:(2).

17. A mirudin. 2010. Analisis Faktor yang Berhubungan dengan Ke jadian Gangguan Jiwa Skizofrenia di Rumah Sakit Jiwa Provinsi Sulawesi Tenggara. Makassar: Program Pascasarjana Uni18. versitas Hasanudin.

Setiyow ati. Y. 2012. Hubungan F ak tor Riwayat Keluarga dan Stresor Psikososial Dengan Kejadi an Skizofrenia

19. di Kabupaten Kebumen. Yogyakarta: Fakultas Kedokteran Universitas Gajah Mada.

20. Arif, I.S. 2006. Skizofrenia Memahami Dinamika Keluarga Pasien. Bandung : Refika aditama.

21. Notoatmodjo, S. 2007. Promosi Kesehatan dan Ilmu Perilaku. Jakarta: Rineka Cipta.

Muhammad Fadli. 2015. Hubungan

22. Tipe Kepribadian Dengan Kejadian Gangguan Jiwa pada Keluarga. Yogyakarta : Stikes Aisyiah.

Erlina, Soewadi, Pramono.D. 2010. Determinan Terhadap Timbulnya Skizofre- nia pada Pasien Rawat Jalan di Rumah Sakit Jiwa Prof.HB Saanin Padang Sumatera Barat : Berita Kedoteran Masyarakat;26.pp. 2.

23. Mallet, R.,Leff, J.,Bhugra, D.,Pang, D., Zhao Jing, H. 2002. Social Environment, Ethnicity and Schizophrenia. Social Psychiatry Section. Instit ute of Psychiatry. De Crepigny Park. London, SES 8AF, UK.

24. Cepi Hidayat, Reini Astuti, Wulan Novika Ambarsari. 2013. Hubungan Masalah Psikososial dengan Kejadian Skizofrenia. Jurnal Kesehatan Budi Luhur Cimahi;8(3).

25. Gilang purnama, Desy Indra Yani, Titin Sutini. 2016. Gambaran Stigma Masyarakat Terhadap Klien Gangguan Jiwa. Jurnal Pendidikan Keperawatan Indonesia;2(1.).

26. Sumarmi DW, Maulina. 2006. Pengaruh Stressor Psikososial Terhadap Depresi dan Gangguan Kesehatan Reproduksi Guru Perempuan di Sekolah Dasar Negeri. Jurnal kesehatan. Yogyakarta: Berita Kedokteran Masyarakat;22(3).

27. Utomo.T.L. 2013. Hubungan Antara Faktor Somatik, Psikososial, dan Sosio Kultur dengan Kejadian Skizofre nia di Instalasi Rawat Jalan RSJD Surakarta. Surakarta: Universitas $\mathrm{Mu}-$ hammadiyah Surakarta.

28. Hasmila Sari, Wildan Sirna. 2015. Faktor Predisposisi Penderita Skizofrenia. Idea Nursing Journal:VI(2).

29. Fajar Rinawati, Moh Alimansur. 2016. Analisis Faktor-Faktor Penyebab Gangguan Jiwa Menggunaan Pendekatan Model Adaptasi Stress Stuart. Jurnal Ilmu Kesehatan; 5(1).

30. Jean, PS., dan Canto, E. 2005. Social Defeat: Risk Factor of Schizophrenia. British Journal of Psychiatry; 187. pp.101-102.

31. Giri Widakdo, Besral. 2013. Efek Penyakit Kronis Terhadap Gangguan Mental Emosional. Jurnal Kesehatan Masyarakat Nasional;7(7). 
32. Read J, Van Os J, Morrison AP, Ross CA. 2005. Childhood Trauma, Psychosis And Schizophrenia: A Literature Review With Theoretical and Clinical Implications. Acta Psychiatry Scandinavica;112:pp.330-350.
33. Sundquist K, F.G. 2004. Urbanisation and Incidence of Psychosis and Depression: Follow-up Study of 4.4 million Women and Men in Sweden. Br J Psychiatry;184.pp.293-298. 